DOI: https://doi.org/10.34069/AI/2021.38.02.18

\title{
Ukrainian Soviet Family: Formative stages
}

\section{Українська радянська сім'я: етапи становлення}

Received: March 3, 2021

\begin{abstract}
The purpose of the article: is to determine the peculiarities of the formation of family policy of the Soviet government and the co-existence of private and public in the household of Ukrainian families during the existence of the Soviet system. Research methods: comparative method, method of analogy, analysis and synthesis method, method induction and deduction were used in the course of the research. The results of the research. A comparative analysis of the peculiarities of the existence of Soviet families at different stages of the Soviet period was conducted. The parallels were drawn between the traditional Ukrainian family in the prerevolutionary period and family innovations in the Soviet period. Practical implication. A generalized description of the position of the Ukrainians as a common element of the Soviet people under the Soviet system is provided. Value/Originality. The role of statistics alongside memories for a better reflection of the daily life of the Ukrainian Soviet family under the conditions of double standards of Soviet society is shown for the first time.
\end{abstract}

Key Words: household, Soviet system, everyday life, marriage, ideology.
Accepted: April 5, 2021

Written by:
Gumeniuk Oksana $^{60}$
https://orcid.org/0000-0002-6639-7325
Durnov Yevhen $^{61}$
https://orcid.org/0000-0002-4249-9829
Shkuratenko Olena ${ }^{62}$
https://orcid.org/0000-0002-1879-0085
Kumeda Tetiana $^{63}$
https://orcid.org/0000-0002-1690-4253
Savytskyi Roman $^{64}$
https://orcid.org/0000-0002-5293-4652

\section{Анотація}

Метою статті: $€$ визначення особливостей становлення сімейної політики радянської влади та співіснування приватного та загальнодержавного у побутовому просторі українських сімей часів існування радянської системи. Методи дослідження: компаративний, метод аналогії, аналізу та синтезу, індукції та дедукції. Результати дослідження. Проведено порівняльний аналіз існування радянських сімей у різні часи існування радянської системи. Проведено паралелі між традиційною українською родиною в дореволюційний період та сімейними нововведеннями в радянський період. Практичне значення. Надано узагальнену характеристику становища українців як загальноскладового елементу радянського народу в умовах існування радянської системи. Наукова новизна. Уперше показано, яку роль відіграють статистичні дані поряд зі спогадами для кращого відображення повсякденного життя української радянської сім'ї в умовах подвійних стандартів радянського суспільства.

Ключові слова: побутовий простір, радянська система, повсякденність, комуністична партія, шлюб,ідеологія.

\footnotetext{
${ }^{60}$ Candidate of Historical Sciences, Associate Professor, Associate Professor of the Department of History of Ukraine of the Faculty of History and Sociology of Rivne State Humanities University, Ukraine.

${ }^{61}$ Doctor of Law, Professor, Deputy Head of Personnel Department of the Ministry of Internal Affairs of Ukraine.

${ }^{62}$ Candidate of Legal Sciences, Associate Professor, Head of the Department of History of State and Law of the National Academy of Internal Affairs, Ukraine.

${ }^{63}$ Candidate of Art History, Associate Professor of the Department of Philosophy of Law and Legal Logic of the National Academy of Internal Affairs, Ukraine.

${ }^{64}$ Candidate of Legal Sciences, Senior Reseacher of the Scientific Institute of Public Law, Ukraine.
} 


\section{Introduction}

Family acts as a social phenomenon that makes up the fundamental principle of human existence, as a system of values and norms of behavior (Donina, Salikhova, Aryabkina, Chernova, \& Kovardakova, 2019, p. 58). It is the most effective means of transmitting cultural traditions, the bearer of social heritage and a stable part of society; therefore, the study of the family helps to trace the mechanism of its interaction with society.

Various principles and ways of studying family and human self-realization in this institution have been developed by a number of philosophers. Economists analyzed the economic nuances of family life, and lawyers were interested in the legal basis for matrimony and family. Family as a socio-psychological group was the object of interest to psychologists; the problems of its right lifehood were relevant to physicians. Sociologists were interested in the development and functioning of the family, patterns of family behavior, roles and formal and informal norms.

In the 1970s everyday history emerged in Germany in the study of the history of ordinary families, at the crossroads of genealogy, ethnography and history. Italian researchers have been able to understand the general, the public through a vision of private processes by narrowing micro historical observations to the family level. The study of the peasant family was facilitated by preparations for rural reform in Ukraine; but the First and Second World Wars contributed to the thorough study of the urban family.

The purpose of this study is to determine the peculiarities of the formation of family policy and the coexistence of private and public in the domestic space of Ukrainian families during the existence of the Soviet system.

\section{Methodology}

The analysis and synthesis method helped to study memoirs, documents, statistical data and recollections of eyewitnesses, which provide an opportunity to analyze the peculiarities of the development of Soviet families on the basis of data on population growth, the number of marriages and divorces. The recollections of eyewitnesses were examined with the help of monographic method, which helped to consider the peculiarities of Ukrainian family during the existence of the Soviet system. Comparative method was used to compare the views of the scholars, who investigated the features of Soviet families and Soviet policy in the area of family relations. This method was also applied to compare the peculiarities of the existence of Soviet families at different stages of the Soviet period. The method of analogy was helpful in drawing parallels between the traditional Ukrainian family in the pre-revolutionary period and family innovations in the Soviet period. Method of induction and deduction was useful when formulating the relevant conclusions.

\section{Literature Review}

Foreign historiography on family history is mostly represented by sociological researches. In particular Hofstede (1998) presents marriage as an attempt to combine (sometimes incompatible) models of male and female responsibilities. Vogel (1972) focuses more on domestic factors of transformation of marital and family relations. Canadian researcher of anthropological processes in modern society Dunn (2004) focuses on the features of marriage customs, which are partly a reflection of the system of family relations. Toffler's (1984) views on family history itself have the form of wave-like structures, so the author believes that now we need to preserve the third wave (one that combines different forms and methods and departs from the classical family), explaining this rapid development of technology in society. Popenoe (1993) traces the characteristic changes in society, which are reflected in family history in general through the prism of the study of the decline of traditional American families.

The empirical base for the study is mainly memoirs, documents, statistical data and recollections of eyewitnesses, which provide an opportunity to analyze the peculiarities of the development of Soviet families on the basis of data on population growth, the number of marriages and divorces. At the same time, the recollections of eyewitnesses concerning the changes in the marriage system in the USSR are no less important. As Pokhilko, Ivanova, and Martynenko (2020, p. 71) correctly pointed out the study of Ukrainian national identity formation in Soviet Union times requires exploration of historiographic works of Ukrainian scholars, among which we distinguish the memoirs and other works of direct participants of the process, as well as archival sources. 
Sadly, just a limited number of works are devoted to the problems of family history research, which, however, present certain aspects of life of Soviet society in its various manifestations. In particular, Stiazhkina (2013) explored the role of women in the everyday life of Soviet life in her works. Hurova (2008) focused on the study of contradictions between ideology and privacy. The work of Koliastruk (2007) describes the features of everyday history in detail, which allows to conduct a comprehensive analysis of the peculiarities of domestic life of Soviet society. Kohanov traces the whole spectrum of ideological influence on the everyday life of Soviet citizens, focusing on the so-called "Soviet ethnotype".

Russian researchers have studied the role of housing, family and neighborly relations against the background of Soviet ideology (Lebina 2006; Pushkarova 2005). Methodological features of the aspects of everyday life of the Ukrainian peasantry, including peasant families were represented in the study by Pavlukhina (2007).

\section{Results and Discussion}

The Bolshevik elite immediately set the task of forming a new family. As the question of the family of the future has been dealt with rather loosely, utopian notions of the death of the family have become widespread. It was proclaimed that marital relations could take any form, as long as they do not harm the race and are not determined by economic oppression. It should be noted that such family policy and ideology did not become official and dominant, but affirmed the need to transform the family in the interests of the State (Kunovska 2008, p.25).

In the 1930 s, matrimony and the family became the exclusive prerogative of jurisprudence. The concepts of "Soviet family" and "socialist way of life" were interrelated in the postwar years.

In the 1960s and 1980s, utopian ideas about the family of the 1920s revived under the influence of the proclaimed victory of socialism, the Cold War, the development of housing, and the extinction of the family's economic function under communism.

A large number of publications on the history of the family in the period 1920 - 1970 made it possible to allocate it to a special branch of historical science. Initially, it focused on demographic changes in the family and household history. But as early as the second half of the 1970s, the issue of intra-family relations and the nuclear family's ties to a larger family began to arise.

From the second half of the 1980s, the family began to be seen as a process, in which demographic, economic, social and political events were constantly intermingled. It was necessary to analyze superior cultural representations and values, as research on family choices of certain behavioural strategies and decisions had matured. Family history had become complex in its nature, as marriage had become a process of family formation, raising children - the process of internal restructuring, aging and death of its members - the special stage of its development.

Most research on matrimony and family models, the structure of the family, the role of women and children, family law and ideology dates back to the 1980s. Although most of that research concerned peasant families, much attention was also paid to the industrial period of the Soviet family's development. Family ties played a major role in the migration from rural to urban areas. These connections facilitated the adaptation and socialization of the newcomers, and also helped to overcome crises (Kunovska, 2008, p. 26).

Gender research in the 1990s once more drew attention to the history of the family, the problems of marital and family relations in historical aspect. Demographic processes and problems of family structure began to be considered by means of historical informatics.

It should be noted that the study of the family in Soviet historiography is mostly ethnographic and descriptive. But later, historical data on family behavior called into question some conclusions of the theory of modernism and the processes of social change through an inventory of existing views on major historical processes, the pace of their development and the importance of industrialization and urbanization (Radaiev, 1995, p. 2)

Thanks to the research on the Soviet family, in the 1980s scientists agreed that the family was the most active agent of power in the process of industrialization. It should be noted that 20 years earlier this theory was subjected to devastating criticism. Since the family reflects the processes of society as a whole, it is important to understand the way relations are built here and the roles are distributed; which is the place of woman in this institution and if her role grows in 
the view of cataclysms and tragedies of society development.

The 1920s are emblematic of this, as they mark the period of intensification of struggle between the new and old, when the concept of family is vague and leads to endless discussions and quarrels. During this period, apart from the highly patriarchal peasant families, there were a small number of urban families who lived entirely on wages. Just husbands worked in the city in most urban families, when the whole family was in the countryside, taking care of the household and providing accommodation.

After the events of 1917 , the new communist ideals began to fill the moral deficit that had formed. Taking into account that young women were actively involved in community service or education, it greatly enhanced their authority in the family and limited their authoritarianism. All this facts (along with the reduction of the difficulties with divorce) gave rise to different moral and value guidelines in life of each family member, acute family conflicts. Age stability and duration of family life were disturbed (Hurova, 2008, p. 180).

As one knows, a certain generation law works when the world changes and the agents of these changes are the representatives of the generation for whom the situation is most uncomfortable. The 1920s gave rise to the family relations of the Soviet individual and had a significant impact on the entire subsequent history of matrimony and family. The active part of the youth tried to take the leading positions in the changing society. The main target in the struggle for a new life was the family as the most vulnerable part of the microsociety (Kahanov, 2019, p.293).

According to the statistics, $20 \%$ of boys and girls did not have one parent in 1923. And this, certainly, could not contribute to stable image of the family (Lebina 2006, p.103). All attempts to create "new Soviet family" look like models of a new society at the macro level. After all, a generation of young people had been trying to find themselves in the new post-revolutionary era and society. Therefore, a mixture of traditions and innovations in the construction of family strategies has created an extremely complex set of values. Besides, attitudes toward matrimony and family were often determined not only by class or party views but also by the pragmatics of living conditions.
Freedom of relations was fueled by discussions and efforts to give them a political color in the student environment. Therefore, the new socialist family was perceived as free co-existence of people with common political views. There were also many who believed that living together distorts human relationships and impoverishes them.

It was not until the early 1930s that the slogan "Strong family - strong State!" entered the arsenal of Soviet propaganda and the Soviet Union adopted a policy of strengthening the institution of matrimony and family. Clearly, the authorities tried to rely on the family to establish control over people's daily lives.

As one knows, the concept of family is a key category in the study of State family policy and an integral indicator of the development of society, which reflects its moral condition and forms the demographic potential.

The concept of family is defined as a social institution, as a form of institutionalization of responsibility, duty, and other social norms united by marriage according to the logical approach. The family as a social institution is characterized by stability, original ability to preserve and transmit certain social norms and values to future generations, interaction with other social institutions and social processes.

The factual approach defines the family as a small social group based on marriage or kinship or adoption, with shared responsibility and assistance. In general, the family is a social system with the characteristics of both a social institution and a small social group. It is the primary part of society, based on marriage and family ties, which performs the most important social functions. It serves as a kind of mediator between the individual and the State, which resists social confrontation and tension, while maintaining traditional values.

With regard to State family policy, the main thing is to understand which families need the aid from the State and which family ideology is disseminated and supported by the State. That is, there must be a system of values, views and guidelines that analyze and outline social problems, and then identify effective ways to establish or change social relations and social phenomena, including civil marriages (Tiazhelnikova, 2006, p. 54). The subsequent promulgation and approval of such an ideology by society initiated the concept of State family 
policy as a monolithic scientific and practical system, confirmed by regulations, programs, concepts, etc.

Social State, as a rule, directs family policy to the formation of such an economic, political and socio-cultural environment, in which the life of the family is socially protected.

If we talk about family policy in narrow sense, it is a variety of benefits and services provided to the married couple with children or single parents, i.e. childbirth assistance, maternity leave and childcare leave, the system of childcare facilities; indirect State support (tax benefits, etc.).

Family policy in a broad sense is everything that the government does and affects the family. This includes employment policy, family law, social services, education, health care, and policies to help families with retirees. As a result, European family policy practices are considered as a set of various family-oriented policies.

Such a diverse process is in constant development and therefore requires the continuous formation of theoretical and methodological foundations.

Family, as a fairly ancient institution, underwent profound changes during the 20th century, especially during the Soviet period. They concerned all aspects of its existence.

The renewal of the economic and social structure of Soviet society, that is, industrialization, urbanization, secularization of consciousness, and the emancipation of women and children, led to these changes. Besides, wars and social cataclysms have effectively distorted an already complex and not always sequential process of modernizing the family with many contradictions.

On the one hand, the institution of the family, like society, has been revolutionized, overcoming the crisis of the patriarchal family and patriarchal family relations that was clearly felt at the turn of the century. On the other hand, the inconsistent and incomplete changes that have taken place in the family have led to new problems. Family as a social institution has largely begun to lose some vital assets for an individual and society. It found itself on the brink of a new crisis due to the breakdown with other social institutions.
Here we should consider the main changes that took place in the family in the USSR during the 20 th century.

In the 1930s, the number of peasant families, of which there was an overwhelming majority in the pre-revolutionary and early post-revolutionary years, began to decline rapidly. But back in the early '40s, there were over 50 percent.

In the 2nd half of the 1980 s, less than $20 \%$ of the population worked in agriculture and forestry. Therefore, the share of peasant families decreased accordingly (Platonov, 1990, p. 54). These developments have marked one of the major changes that have occurred with the family: the productive activities of family members moved outside the family. This dramatically changed the whole nature of its lifestyle.

Thus, two processes took place in parallel: on the one hand there was the so-called "re-peasantry" of the families, and on the other hand - the transformation of rural families, which made up the majority, in urban ones. The number of urban families more than doubled in the pre-war period (1926 - 1939), while the country's population grew by no more than $16 \%$. Clearly, we should not forget that the Holodomors played their role in this situation.

In the larger country, the dominance of urban families rapidly increased, although the process has been uneven, both in pace and in number (Pushkarova, 2005, p. 97). As one knows, the family reflects the problems inherent in society as a whole. But if certain material problems are resolved with a successful solution of economic problems at the State level, then there are a number of shortcomings that are not solved only by economic or social development, which dictate the family policy of the State. After all, decisions made in various spheres of social life affect the family, although not directly aimed at it. Therefore, the family policy of the State is a component of social policy.

Various areas of social policy are often ineffective, there is a lack of coherence among them, as they do not view the family as a whole and do not take into account the specifics of its functioning and development, so there is a danger of encroachment on its sovereignty. There are many examples of the ways the State or the church or other institutions have influenced the family ideology, giving priority to certain types of family, its forms. This justified State 
intervention in the affairs of the family for the sake of the society.

However, the practice has shown that ignoring the inner desires of the family itself nullifies all declared measures, as the family can protect its sovereignty. Therefore, family policy has always refocused on a social or qualitative goal. Clearly, family pressure persists, but in milder forms. Still, benefits for some types of family discriminate against other types of family, creating discomfort for both childless and singlechild families, and sometimes for large families.

Given this, the so-called "neutrality" of State family policy seems to be self-evident. But the experience of many generations of different countries has shown that this "neutrality" is not as simple as it seems. After all, it is impossible to take into account all the criteria, because what is neutral according to one of the criteria is absolutely not a neutral according to the other one. Moreover, collective interests objectively limit the sovereignty of the family, and therefore make a completely neutral family policy impossible. It only deepens the compromise between the interests of many families and the interests of the social communities on whose behalf the State conducts its policies.

Clearly, many State institutions involved in the implementation of family policy do not use universal recipes, because they do not exist. But following certain principles allow to create a kind of view of a compromise. This includes both the principle of family sovereignty and the principle of individual sovereignty; the principle of expanding freedom of choice, and the principle of self-reliance; the principle of social protection of the family, and the principle of social partnership. Behind all this should be the principle of differentiation of family policy of the State.

When pursuing family policy, one should not impose a certain type of family behavior on families, minimizing interference in family affairs. At the same time, no one abolishes the generally accepted moral and legal social norms.

Certain measures that restrict the freedom of expression of some family members in favor of others are unacceptable. This leads to the artificial preservation of outdated stereotypes of behavior of all family members.

The sovereignty of the family is realized in the freedom of choice. Therefore, bringing or directing the family to a single decision, even if generously confirmed and protected by law, threatens the degree of family freedom. The most acceptable method is when different options for family development exist and are supported by the State in parallel, creating new competitive choices.

If the State bases its family policy on the socalled paternalism, it leads to the incompatibility of family sovereignty with social sovereignty, as in this case family cannot make any decisions independently and freely, since it does not have a predominant responsibility for the welfare, upbringing and maintenance of children, for the family climate, for the support of its elderly members. The result of the work and efforts of all its members contributes to the harmonious development of any family. The less are the families dependent on social patronage, benefits, and free services the more successful they are.

At the same time, the State is obliged to take care of the well-being of the families who, for one or another reason, are not able to fully perform their functions and be responsible for their own wellbeing. Every family should have a minimum income and living conditions, as well as legal protection. At the same time, the criteria for selecting those who really need help should be strict, fair; the help should be really needed and targeted.

World practice shows that the most influential subject of family policy is the State. But the family as the object of this policy develops fully and harmoniously when the state does not make decisions alone as the monopolist, but collegially with other civic institutions. These are religious and secular organizations and movements that are direct participants in the discussion and implementation of family policy measures.

Since any society is quite heterogeneous, it is necessary, if possible, to take into account certain features and implement differentiated policies in relation to existing socio-demographic situations and family models (Vail, 1998, p.32).

In the late 70's the International Notre Dame Seminar on Family Policy, which was held in 1978 in the United States formulated four basic value systems that defined family policy in America and the West. These were:

the traditional system of values, based on the large family (more typical for Belgium and France); 
the idea of distributive justice (typical for the most developed democracies);

the development of the family as an institution of socialization (typical for Germany),

new social ideology of the value of individual development (typical for Scandinavia).

Various family associations (rural, religious, parental children with certain developmental disabilities, etc.) played an important role.

The Soviet Union had its own specifics of family policy. It is especially interesting for us in relation to Ukraine as the specific region for all public policy systems. In 1947 the Verkhovna Rada of the USSR prohibited the marriage of citizens of the USSR with the foreigners. The phenomenon of resettlement from other parts of the country had a direct impact on the future of the Ukrainian family. It particularly affected the western regions of Ukraine.

Since mid-1946, 85,000 party officials have been sent to Western Ukraine from the other regions of the Soviet Union (we know this process as sovietization).

In 1961, the urban population of Ukraine was 20.6 million people; and by 1986 it had grown by $63.6 \%$ (to 33.7 million). During this period, the rural population decreased by $23 \%$ due to industrial development and the decline of the village; even the term "unpromising villages" appeared at this time (Shubkin, 1970, p. 118). In 1968, the all-Union legal act was adopted - the Fundamentals of Marriage and Family Legislation of the USSR. The Codes of all union republics, which regulated family relations, were developed on its basis.

Qualitative changes in family life were inseparable from quantitative ones. In general, family has not lost its role as one of the main forms of human community. The share of people living with families remained quite stable, close to $90 \%$ (in 1939 it was $89.4 \%$; in $1959-89.8 \%$; in $1970-90.1 \%$; in $1979-89.8 \%$; in $1989-$ $89.5 \%$ ). The average family size after 1939 has decreased markedly, as in 1939 it was 4.1 per family in 1939; in $1959-3.7$; in $1970-3.7$; in 1979 and $1989-3.5$. This is due to a significant decrease in the share of large families with five or more members. In 1939 there were more than $35 \%$ of such families; in 1959 their share decreased to $26 \%$, in 1989 it was only $18 \%$. According to the average all-Union indicators, large regional differences can be seen. In 1989, the average family size in Latvia and Estonia was 3.1; in the Russian Federation, Ukraine, Belarus and Lithuania - 3.2. In the republics of Central Asia, these figures were: in Uzbekistan 5.5 people; Turkmenistan - 5.6; Tajikistan - 6.1. Among the rural population of these republics, the average family size exceeded 6 persons. The share of large families of 5 or more people was significant (more than 70\% in 1989). Currently, the most common are three types of family: A a married couple with or without children (nuclear family), B - one of parents with children (incomplete nuclear family), $\mathrm{C}$ - married couple with children or without children with one of the parents of the couple and other relatives (complex family) (State Statistics Committee, 1990).

In 1979, such families accounted for more than $91 \%$ of all families. These types of families were the most common in the past, although their predominance was not so significant. Obviously, the growing share of the three main types of the families is a historical trend associated with the changes described earlier. At the same time, the share of nuclear families is increasing and the share of complex families is decreasing.

\section{Conclusion}

Families are formed and disappear as a result of marriages, the birth of children, the division of existing families and the death of their members. What has changed during these processes?

Nowadays, as before, most men and women of each generation are getting married. According to the 1989 census, there were only $3.2 \%$ of men and $3.3 \%$ of women who were never married between the ages of 45 and 49 . This figure is even lower than in the pre-revolutionary years, when the level of marriages was quite high. There have been no fundamental changes in the age requirement for the first marriage without focusing on changes related to social cataclysms, wars, etc. (State Statistics Committee, 1990).

According to the 1989 census, the average age of first the marriage for men was 24.4 years, for women - 21.7. This differed little from the figures of the late 19th century. Significant changes were observed only in some republics of the Caucasus and Central Asia, which were characterized by early marriageable age of women. After the changes that have taken place in these areas, they are characterized by rather late marriages. In 1989, the share of women aged $20-24$, who were never married, was $47 \%$ in Azerbaijan, $41 \%$ in Georgia, and $46 \%$ in Turkmenistan, 34\% in Russia, $29 \%$ in Ukraine, $38 \%$ in Latvia (State Statistics Committee 1990). 
The new phenomenon - the spread of unregistered marriages - attracted the attention of researchers in the late 80's. Although direct statistical assessment of this phenomenon is difficult, there are attempts to assess it indirectly, due to the dynamics of illegitimate births.

Thus, one can see that the issue of family and marriage has shifted more to the realm of jurisprudence than to history. Besides, another stable direction - the contrast of family and marriage under capitalism and socialism marked in historiography in connection with the declaration of «the victory of socialism in the USSR». In the postwar period, this problem began to be developed in the context of the interconnected concepts of "Soviet family" and "socialist way of life". As a result, a number of myths have been established in the scientific literature: the degradation of bourgeois marriage as opposed to the flourishing of the socialist family; the idea of marriage under capitalism as a modification of commodity-money relations; sharp opposition of family functions under capitalism and socialism, etc.

\section{References}

Donina, O., Salikhova, A., Aryabkina, I., Chernova, Y., and Kovardakova, M. (2019). "Value-Semantic Filling of the Family Concept and Value Orientations of Russian Modern Young People Family Life". Amazonia Investiga, Vol. 8(22), pp. 58-68. https://amazoniainvestiga.info/index.php/amazo nia/article/view/28.

Dunn, C. (2004). Cultural models and metaphors for marriage: an analysis of discourse at Japanese wedding receptions. Journal of the society for psychological anthropology, Vol. 32(3), pp. 348-373.

Hofstede, G. (Ed.). (1998). Cross-cultural psychology series, Vol. 3. Masculinity and femininity: The taboo dimension of national cultures. California: Sage Publications, Inc.

Hurova, O. (2008). Soviet underwear: between ideology and everyday life. Moscow: New Literary Review.

Kahanov, Y. (2019). Constructing the "Soviet man" (1953-1991): Ukrainian version. Zaporizhia: Inter-M, 432. Available online. https://uamoderna.com/book/yurij-kaganovbook. Consultation date: 10/02/2021.

Koliastruk, O. (2007). "The Subject of History of Everyday Life: Historiographical Review of its Formation in Foreign and National Historical Science". Ukrainian Historical Journal, Num. 1, pp. 174-184. Available online. In:
http://history.org.ua/JournALL/journal/2007/1/1 3.pdf. Consultation date: 10/02/2021.

Kunovska, O. (2008). "Quo vadis History of Everyday Life?" Historiographical research in Ukraine: Collection of scientific works, Issue 18, pp. $21-30$.

Lebina, N. (2006). Encyclopedia of Banalities: Soviet Everyday Life: Contours, Symbols, Signs. St. Petersburg: Dmitriy Bulanin. Available online.

In:

http://ecsocman.hse.ru/text/33438087/.

Consultation date: 10/02/2021.

Pavlukhina, V. (2007). Methodological foundations for the study of the everyday life of the Ukrainian peasantry in the 60's and 80's of the 20th century. Ukraine of the twentieth century: culture, ideology, politics, Issue 11, pp. 434-443.

Platonov, O. (1990). Memories of the national economy. Moscow: Soviet Russia.

Popenoe, D. (1993). American family decline, 1960-1990: A review and appraisal. Journal of Marriage and Family, Vol. 55(3), pp. 527-542. Pokhilko, O., Ivanova, I., and Martynenko, D. (2020). "National Identity Formation under Statelessness: Experience of Ukraine in Soviet Times". Amazonia Investiga, Vol. 9(32), pp. $70-80$. https://doi.org/10.34069/AI/2020.32.08.8.

https://amazoniainvestiga.info/index.php/amazo nia/article/view/1446

Pushkarova, N. (2005). "History of everyday life" and "history of private life": content and correlation of the concepts". Social History, Num. 1, pp. 98-100.

Radaiev, V. (1995). Social stratification in Soviet society. Social stratification. Moscow: Aspekt Press. Available online. In: https://www.twirpx.com/file/2182599/.

Consultation date: 10/02/2021.

Shubkin, V. (1970). Sociological experiments (Methodological issues of social research). Moscow: Mysl.

State Statistics Committee. (1990). 1989 AllUnion Population Census: Number of families and groups by size of Union Republics. Vesnik statistiki, Num. 6. pp. 78 - 79. Available online. In:

http://istmat.info/files/uploads/17594/naselenie_ sssr._po_dannym_vsesoyuznoy_perepisi_nasele niya_1989g.pdf. Consultation date: 10/02/2021. Stiazhkina, O. (2013). Individual in the Soviet province: development of denial. Donetsk: Knowledge. Available online. https://uamoderna.com/md/212-212. Consultation date: 10/02/2021.

Tiazhelnikova, V. (2006). "Households of citizens in the 1960 - 1980s: structure and 
strategies of economic behavior". Domestic history, Num. 4, pp. 53-60. Available online. In: https://elibrary.ru/item.asp?id=9246090.

Consultation date: 10/02/2021.

Toffler, A. (1984). The Third Wave. New York: Bantam Press.
Vail, P. (1998). The 60s: The World of Soviet Man. Moscow: New Literary Review.

Vogel, E. (1972). Family and relationship. American sociology: prospects, problems, methods (translation from English by $T$. Parsons). Moskow: Progress. 